\title{
$N$ availability and mechanisms of $N$ conservation in deciduous and semideciduous tropical forest legume trees
}

\author{
Ana Lúcia da Silva Lima ${ }^{1}$, Fábio Zanella ${ }^{1}$, Marlene Aparecida Schiavianto ${ }^{2}$ and \\ Claudia Regina Baptista Haddad ${ }^{2,3}$
}

Received: Juny 13, 2005. Accepted: March 3, 2006

\begin{abstract}
RESUMO - (Disponibilidade de N e mecanismos de conservação de N em leguminosas arbóreas decíduas e semidecíduas de floresta tropical). Antes da abscisão, os nutrientes são removidos das folhas e redistribuídos para outras partes da planta. Quando se relaciona o reaproveitamento de nutrientes à fertilidade do solo, ou à longevidade foliar, os dados da literatura são controversos. Foram comparados mecanismos de conservação de nitrogênio $(\mathrm{N})$ em quatro leguminosas arbóreas (Hymenaea courbaril L. var. stilbocarpa (Hayne) Lee et Lang., Lonchocarpus guilleminianus (Tul.) Malme, Enterolobium contortisiliquum (Vell.) Morong e Peltophorum dubium (Spreng.) Taub.), com longevidades foliares diferentes, de uma Floresta Semidecídua, remanescente da mata Atlântica. O objetivo do trabalho foi verificar se esses mecanismos são diferentes nas quatro espécies e se são afetados pela longevidade foliar e disponibilidade de N, tanto mineral, como proveniente de fixação simbiótica, no caso de L. guilleminianus e E. contortisiliquum, que apresentam associação com rizóbios. As plantas foram cultivadas em vasos contendo solo da mata, enriquecido (50 ou $100 \mathrm{mg} \mathrm{de} \mathrm{NH}_{4} \mathrm{NO}_{3}$ planta-1 ${ }^{-1}$ semana-1) ou não com $\mathrm{N}$ mineral. $H$. courbaril, uma semidecídua que não fixa $\mathrm{N}$ e possui a maior longevidade foliar dentre as espécies analisadas, apresentou a maior eficiência de reaproveitamento de $\mathrm{N}$ (ERN), proficiência de reaproveitamento de $\mathrm{N}$ (PRN) e eficiência de utilização de $\mathrm{N}$ (EUN). O acréscimo de $\mathrm{N}$ no solo e a presença de fixação simbiótica de N levaram a decréscimos em ERN, PRN e EUN.
\end{abstract}

Palavras-chave: longevidade foliar, fixação de nitrogênio, eficiência de reaproveitamento de nitrogênio, proficiência de reaproveitamento de nitrogênio, eficiência do uso de nitrogênio

\begin{abstract}
N availability and mechanisms of $\mathrm{N}$ conservation in deciduous and semideciduous tropical forest legume trees). Prior to abscission, nutrients are redeployed from leaves and redistributed to other parts of the plant. Data comparing nutrient resorption to soil fertility and leaf life span remains controversial in the literature. We compared nitrogen $(\mathrm{N})$ conservation mechanisms among four legume trees with different leaf life spans (Hymenaea courbaril L. var. stilbocarpa (Hayne) Lee et Lang., Lonchocarpus guilleminianus (Tul.) Malme, Enterolobium contortisiliquum (Vell.) Morong and Peltophorum dubium (Spreng.) Taub.), from a semideciduous tropical forest, remnant of the Atlantic Forest. We hypothesized that these mechanisms differ among the four species and are affected by their leaf life span and by the availability of $\mathrm{N}$, both as a mineral in the soil and, in the case of L. guilleminianus and E. contortisiliquum, from symbiotic nitrogen fixation (SNF), as these species form associations with rhizobia. The plants were grown in a greenhouse using pots filled with forest soil, enriched ( 50 or $100 \mathrm{mg}$ of $\mathrm{NH}_{4} \mathrm{NO}_{3}$ plant ${ }^{-1}$ week $^{-1}$ ) or not with nitrogen. H. courbaril, a semideciduous tree, without SNF, and with the highest leaf life span, presented the greatest N-resorption efficiency (NRE), N-resorption proficiency (NRP) and N-use efficiency (NUE). Increase in soil $\mathrm{N}$ and the presence of symbiotic $\mathrm{N}$ fixation led to a decrease in NRE, NRP and NUE.
\end{abstract}

Key words: leaf life span, nitrogen fixation, nitrogen resorption efficiency, nitrogen resorption proficiency, nitrogen-use efficiency

\section{Introduction}

Evergreen species have a lower concentration of leaf nutrients and a longer leaf life span than deciduous species. These are important mechanisms for nutrient economy, making possible the colonization of low fertility soils (Alerts 1996; Eamus \& Prichard 1998). Removal of nutrients from leaves prior to abscission and their redeployment to other tissues is known as nutrient resorption (Wright \& Westoby 2003) and is considered an important adaptation of certain species to less fertile ecosystems (May \& Killingbeck 1992; Pugnaire \& Chapin 1993). Therefore, evergreen species are likely to show greater resorption efficiency in comparison to deciduous ones. However, consensus has not been reached in the literature comparing these two groups of plants (Aerts 1996; Lal et al. 2001) and attempts to relate nutrient resorption efficiency to soil fertility have

\footnotetext{
1 Universidade Luterana do Brasil, Centro Universitário Luterano de Ji-Paraná, Departamento de Biologia e Agronomia, C. Postal 271, 78961-970 Ji-Paraná, RO, Brasil

2 Universidade Estadual de Campinas, Instituto de Biologia, Departamento de Fisiologia Vegetal, C. Postal 6109, 13083-862 Campinas, SP, Brasil

3 Corresponding Author: chaddad@unicamp.br
} 
led to controversy (Aerts 1996; Eckstein et al. 1999; Cordell et al. 2001; Carrera et al. 2003).

Killingbeck (1996) concluded that plants which perform symbiotic $\mathrm{N}$ fixation (SNF) presented lower $\mathrm{N}$-resorption proficiency (NRP), and N-resorption efficiency (NRE) than those which do not. Resorption efficiency is the difference between the nutrient concentration in green leaves and senescent leaves, given as a percentage (Distel et al. 2003), whilst resorption proficiency is the absolute value by which nutrients are reduced in senescent leaves. Thus, the lower the concentration of a nutrient in senescent leaves, the greater the resorption proficiency (Killingbeck 1996).

The presence of root nodules in legumes that have nitrogen-fixing potential is an indication that such plants possess another nitrogen $(\mathrm{N})$ source in addition to that available from the mineral and organic fraction of the soil. However, these nodules may not be functional. The efficiency of the $\mathrm{N}_{2}$ fixation process can be evaluated by the nitrogenase activity, presence of leghemoglobin and protein concentration within the nodules (Cresswell et al. 1992; Sprent 2001).

There are indications that plants with a long leaf life span produce more organic material per unit of mineral nutrient than those with shorter leaf life spans (Chapin 1980; Aerts et al. 1999). This ratio represents the nutrient use efficiency (Vitousek 1982). A number of studies have stressed that nutrient use efficiency also increases as soil nutrients decrease (Vitousek 1984; Distel et al. 2003). However, no differences were found in the N-use efficiency (NUE) between two evergreen species and two deciduous species from the Australian savanna (Eamus \& Prichard 1998).

The aim of the present work was to compare $\mathrm{N}$ conservation mechanisms (NRE, NRP and NUE) among four Semideciduous Forest legume trees with different leaf life spans, growing under different availabilities of nitrogen (in mineral form or derived from SNF).

\section{Material and methods}

Characterization of species and site-Four legume tree species from the Santa Genebra Reserve, Campinas, São Paulo State, Brazil (2249’45” S, 4706’33” W) were chosen for this study. The site is a fragment of the Atlantic Forest (Morellato \& Leitão Filho 1995) with an area of $251,000 \mathrm{~m}^{2}$ and an altitude of $670 \mathrm{~m}$. The soil is classified as Distrophic Purple Latossoil (Oliveira et al. 1979). The Santa Genebra Forest is classified as a Semideciduous Seasonal Forest as it harbors a diverse number of tree species that shed their leaves during the cold and dry season (Morellato \& Leitão Filho 1995). Two of the species used in this study are classified as semideciduous species and the other two as deciduous. The semideciduous species shed their leaves during a definite time of the year but are never totally leafless, whilst the deciduous species shed all their leaves during a specific time of the year, remaining totally bare for a period that can vary from a week to several months (Morellato et al. 1989). The classification of the four legumes according to the subfamily, presence of nodules for SNF and leaf shedding can is found in Table 1.

Plant material - Seeds of Hymenaea courbaril L. var. stilbocarpa (Hayne) Lee et Lang., Lonchocarpus guilleminianus (Tul.) Malme, Enterolobium contortisiliquum (Vell.) Morong and Peltophorum dubium (Spreng.) Taub. were collected in 2001 and stored at a temperature of $10{ }^{\circ} \mathrm{C}$. Seeds from $H$. courbaril and E. contortisiliquum were scarified with concentrated sulphuric acid for 1 hour and those from $P$. dubium were scarified for 30 minutes. They were then washed with distilled water. Seeds from the four species germinated at a temperature of $25{ }^{\circ} \mathrm{C}$ within a 12-hour photoperiod. The plants were grown in a greenhouse, under natural temperature and sunlight conditions, in plastic pots $(5 \mathrm{~L}$

Table 1. Classification of the legume tree species according to subfamilies, presence $(+)$ or absence $(-)$ of symbiotic nitrogen fixation nodules and leaf deciduity.

\begin{tabular}{|c|c|c|c|}
\hline Species & Subfamily & Nodulation (Reference) & Leaf deciduity (Reference) \\
\hline $\begin{array}{l}\text { Hymenaea courbaril L. var. stilbocarpa } \\
\text { (Hayne) Lee et Lang }\end{array}$ & Cesalpinoideae & - (Faria et al. 1989) & Semideciduous (Lorenzi 1992) \\
\hline Lonchocarpus guilleminianus (Tul.) Malme & Papilionoideae & $+($ Faria et al. 1989) & $\begin{array}{l}\text { Semideciduous (Morellato et al. } \\
\text { 1989; Lorenzi 1992) }\end{array}$ \\
\hline Enterolobium contortisiliquum (Vell.) Morong & Mimosoideae & $+($ Faria et al. 1989$)$ & Deciduous (Lorenzi 1992) \\
\hline Peltophorum dubium. (Spreng.) Taub. & Cesalpinoideae & - (Faria et al. 1989) & Deciduous (Lorenzi 1992) \\
\hline
\end{tabular}


capacity) filled with soil from the Santa Genebra Forest. Irrigation was performed through daily sprinklings. The experiment was concluded after 419 days, when all plants (approximately $50 \mathrm{~cm}$ tall) presented senescent leaves for analysis.

The following soil treatments were applied from February 2002 to May 2003: control plants, in which soil from Santa Genebra Reserve was used, and plants grown in this same soil but enriched with mineral $\mathrm{N}$ (50 or $100 \mathrm{mg}$ of $\mathrm{N} \mathrm{plant} \mathrm{w}^{-1} \mathrm{week}^{-1}$ ) in the form of $\mathrm{NH}_{4} \mathrm{NO}_{3}$.

In order to ensure nodulation in species associated with rhizobia (with symbiotic nitrogen fixation-SNF), inoculation was carried out with slow growth rhizobia strains $(2 \mathrm{~mL} /$ pot $)$, previously isolated from root nodules (Vincent 1970), collected from the same species in situ.

Leaf characterization - Growth curves were produced based on the length of the central rachis, so as to verify when leaf growth was completed and nutrient resorption could start. The leaves were classified as mature green (when they had reached their maximum growth) and senescent (with a yellowish coloration and dropped when touched). The mean and standard deviation of the rachis length for mature green leaves of each species were as follows: $H$. courbaril: $8.8 \mathrm{~cm}$ \pm 2.2 ; L. guilleminianus: $17.8 \mathrm{~cm} \pm 3.5 ;$ P. dubium: $6.7 \mathrm{~cm} \pm 0.4$ and $E$. contortisiliquum: $13.9 \mathrm{~cm} \pm 2.9$. Leaf life span was monitored using dated plastic tape placed around $1 \mathrm{~cm}$ long petioles of the same leaves described above.

Total chlorophyll concentration was determined in mature green and senescent leaves in order to find the point in which its concentration decreases and thus the beginning of senescence and $\mathrm{N}$ resorption processes (Smart, 1994 - data not shown).

Determination of N-resorption efficiency (NRE), $\mathrm{N}$-resorption proficiency (NRP), N-use efficiency (NUE) and total $\mathrm{N}$ in tissues- Mature green leaves and senescent leaves were collected on a single occasion and at the same time for all four species. Subsamples of leaves weighing $100 \mathrm{mg}$ per plant were dried at $65^{\circ} \mathrm{C}$ for 7 days and total $\mathrm{N}$ determined according to Nelson \& Sommers (1973). The N concentration in senescent leaves was used as an indicator of NRP (Killingbeck 1996).

$\mathrm{NRE}$ was calculated by: $\mathrm{NRE}=\left(\mathrm{N}_{\text {mature green }}-\mathrm{N}\right.$ senescent $) / \mathrm{N}_{\text {mature green }} \times 100 \%$, where: $\mathrm{N}_{\text {mature green }}=\mathrm{N}$ in mature green leaves, $\mathrm{N}_{\text {senescent }}=\mathrm{N}$ in senescent leaves (Pugnaire \& Chapin 1993).

NUE was calculated by: NUE (g of dry mass $\mathrm{mg}^{-1}$ of $\mathrm{N})=1 /\left[\mathrm{N}_{\text {mature green }} \times(1-r)\right]$, where: $\mathrm{N}_{\text {mature green }}=$ total $\mathrm{N}$ concentration in mature green leaves and $r=$ NRE expressed in terms of a fraction (Aerts et al. 1999).

Determination of nodule activity - The leghemoglobin level was determined according to Becana et al. (1986) whilst total proteins were determined according to Bradford (1976). Concentrations of total proteins and leghemoglobin were calculated based on root dry mass. Specific nitrogenase activity was assessed by the acetylene reduction technique (Hardy et al. 1968) on intact plants (Gomes \& Sodek 1984). SNF is evident in the two species (Tab. 2).

Table 2. Nodules dry mass (DM), leghemoglobin (LegHb) and total protein concentrations and nitrogenase activity (ARA), of semideciduous (Lonchocarpus guilleminianus) and deciduous (Enterolobium contortisiliquum) legume trees with symbiotic $\mathrm{N}$ fixation, cultivated in soil from the Santa Genebra Reserve. Data represent means \pm standard deviation $(n=5)$.

\begin{tabular}{lrc}
\hline Analyses & L. guilleminianus & E. contortisiliquum \\
\hline $\mathrm{DM}(\mathrm{g})$ & $0.13 \pm 0.02$ & $0.52 \pm 0.17$ \\
LegHb $\left(\mathrm{mg} \mathrm{g}^{-1} \mathrm{DM}\right)$ & $2.46 \pm 0.17$ & $3.61 \pm 0.44$ \\
Total protein $\left(\mathrm{mg} \mathrm{g}^{-1} \mathrm{DM}\right)$ & $12.58 \pm 1.30$ & $17.12 \pm 1.79$ \\
ARA (ethylene & $8.73 \pm 0.70$ & $27.97 \pm 7.69$ \\
$\quad \mu$ moles g $\left.^{-1} \mathrm{DM} \mathrm{h}^{-1}\right)$ & & \\
\hline
\end{tabular}

Experimental design and statistical analysis - Statistical analyses were performed with SAS/STAT software (1990). The normality of data distribution was determined with the Kolmogorov-Smirnov test. The data were subjected to an analysis of variance and the means compared for significant differences by Duncan's Multiple Range test at 5\% probability level. Percentage data in NRE analyses were converted into arcsine, and analysis of variance was then applied. A total of five replicates (each represented by one leaf for each plant) was used for each species, in a completely randomized design, for chlorophyll, total protein, leghemoglobin and nitrogenase activity analyses, whereas three replicates were used for NRE, NRP and NUE calculations, and ten replicates for leaf life span and leaf growth curves.

\section{Results and discussion}

Semideciduous species (mean \pm standard deviation for $H$ courbaril: $419 \pm 54.8$ days and for L. guilleminianus: $340 \pm 9.7$ days) presented leaf life spans at least twice those of the deciduous species 
(P. dubium: $152 \pm 23.1$ days and E. contortisiliquum: $139 \pm 11.9$ days). A longer leaf life span is regarded as a mechanism for conserving nutrients since it reduces the loss of minerals during leaf abscission (Aerts 1995; 1996; Carrera et al. 2003; Eckstein et al. 1999).

Nodules were found only in plants growing in soil without the addition of $\mathrm{N}$ (control) (Tab. 2) which could be explained by the fact that mineral $\mathrm{N}$ applications hinder nodule formation. Studies have shown that applications of $\mathrm{NH}_{4}^{+}$and $\mathrm{NO}_{3}^{-}$inhibit the association of rhizobia during the formation of the nodules (Streeter 1988; Guo et al. 1992; Waterer \& Vessey 1993; Gonçalves et al. 1999).

Figure 1 shows the N-resorption efficiency (NRE) results for the four species. When comparing the species without symbiotic nitrogen fixation (SNF), the semideciduous species, $H$. courbaril, had a greater NRE than the deciduous species, P. dubium. Regarding the relationship between NRE and $\mathrm{N}$ availability from symbiotic fixation, the species with SNF (L. guilleminianus and E. contortisiliquum) presented a lower NRE in relation to the others. Adding $\mathrm{N}$ to the soil also resulted in a decrease in NRE (Fig. 2).

The decrease in NRE given a greater availability of $\mathrm{N}$ is further evidence of the existence of a negative feedback mechanism between resorption efficiency and soil fertility (Berendse 1994; Jones et al. 1994; Aerts 1995; Feller et al. 1999; Enoki \& Kawaguchi 1999; Anderson \& Eickmeier 2000). Moreover, NRE is reportedly lower in species with SNF than in species that do not fix $\mathrm{N}_{2}$ (Côte \& Dawson 1986; Côte et al. 1989; Killingbeck 1993). However, the relationship between soil fertility and NRE should not be generalized. Feller et al. (2003) found that the addition of $\mathrm{N}$ to the soil did not alter the NRE of Metrosideros

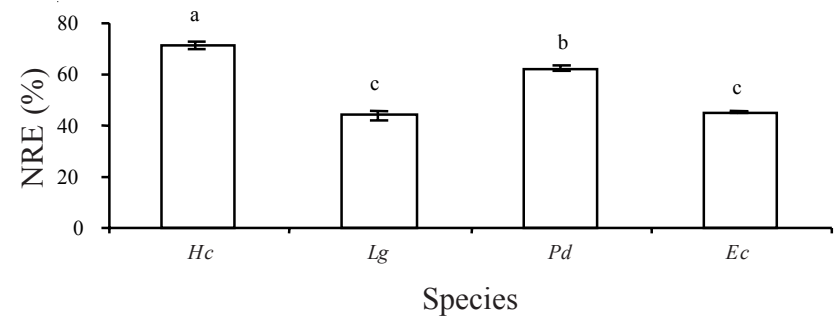

Figure 1. N resorption efficiency (NRE) in semideciduous and deciduous legume trees with and without symbiotic $\mathrm{N}$ fixation (SNF): Hc - Hymenaea courbaril (semideciduous - without SNF), Lg - Lonchocarpus guilleminianus (semideciduous - with SNF), $P d$ - Peltophorum dubium (deciduous - without SNF), and Ec - Enterolobium contortisiliquum (deciduous - with SNF). Bars indicate standard deviation $(\mathrm{n}=3)$. Different letters indicate differences between species (Duncan 5\%).
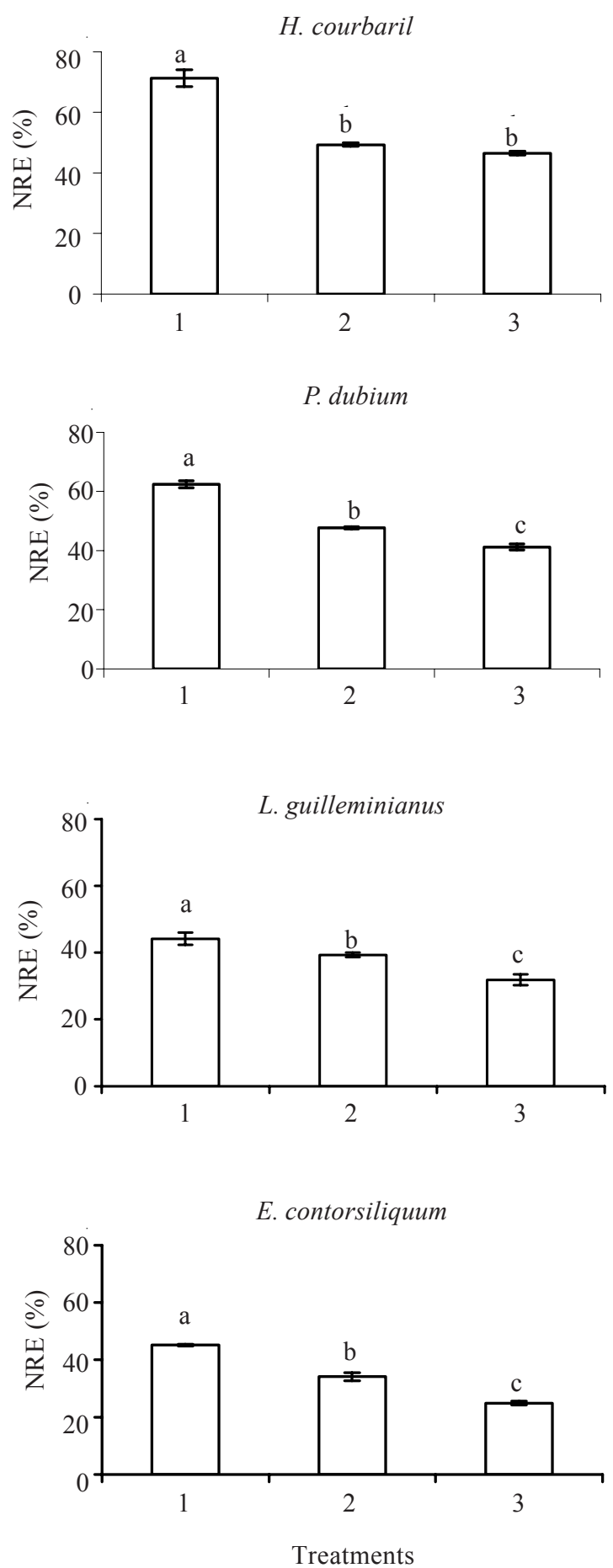

Figure 2. N resorption efficiency (NRE) in semideciduous and deciduous legume trees with and without simbiotic $\mathrm{N}$ fixation (SNF): H. courbaril (semideciduous - without SNF), L. guilleminianus (semideciduous - with SNF), P. dubium (deciduous - without SNF), and E. contortisiliquum (deciduous - with SNF). Plants were grown in different soils: 1 - soil from the forest, 2 soil from the forest enriched with $50 \mathrm{mg}$ of $\mathrm{NH}_{4} \mathrm{NO}_{3}$ plant ${ }^{-1}$ week $^{-1}$ and 3 - soil from the forest enriched with $100 \mathrm{mg}$ of $\mathrm{NH}_{4} \mathrm{NO}_{3}$ plant ${ }^{-1}$ week ${ }^{-1}$. Bars indicate standard deviation of means $(n=3)$. Different letters indicate differences between treatments (Duncan 5\%). 
polymorpha. Likewise, Distel et al. (2003) did not find any difference in the NRE of Stipa gynerioides, a species restricted to a less fertile environment, and Stipa brachychaeta, a species that grows in a fertile environment. The authors concluded that the different distribution of the two species cannot be explained by NRE efficiency.

Resorption proficiency is considered a more stable indicator of the plant capacity to reuse nutrients than resorption efficiency (Killingbeck 1996). An increase in the availability of $\mathrm{N}$ for the plant, due to SNF, leads to a decrease in N-resorption proficiency (NRP), that is, there is an increase in the concentration of $\mathrm{N}$ in the senescent leaves (Killingbeck 1996; Killingbeck \& Whitford 2001). The data from the present study agree with these observations, given that the $\mathrm{N}$ concentrations found in senescent leaves for species without SNF were much lower than those with SNF (Fig. 3). After comparing the NRP of many species, KIllingbeck (1996) established that this parameter can be considered efficient when the concentration of $\mathrm{N}$ in senescent leaves is lower than $7.0 \mathrm{mg} \mathrm{g}^{-1}$ of dry mass. Our results show that species without SNF had NRP values that were much lower than $7.0 \mathrm{mg} \mathrm{g}^{-1}$ of dry mass $\left(2.7 \mathrm{mg} \mathrm{g}^{-1}\right.$ of dry mass for $H$. courbaril and $3.6 \mathrm{mg} \mathrm{g}^{-1}$ of dry mass for $P$. dubium) whilst the NRP values of the species with SNF had values that exceeded this threshold $\left(9.0 \mathrm{mg} \mathrm{g}^{-1}\right.$ of dry mass for L. guilleminianus and $7.1 \mathrm{mg} \mathrm{g}^{-1}$ of dry mass for E. contortisiliquum).

Distel et al. (2003) verified that species which inhabit less fertile soils present high NRP values when compared to species growing in fertile soils. Our results agree with this observation since an increase in the availability of $\mathrm{N}$ by adding it to the soil, led to an

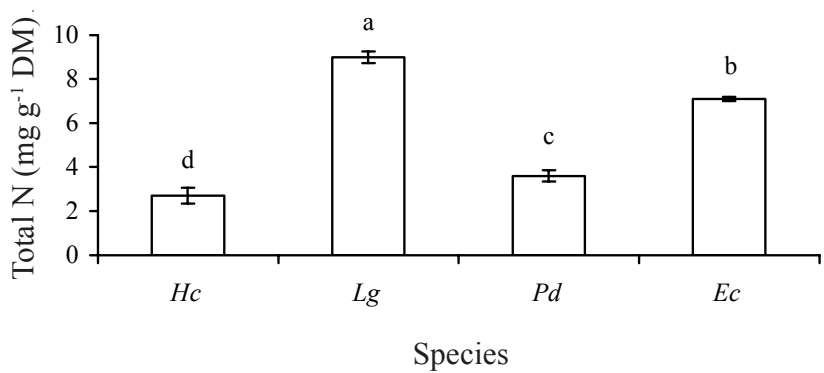

Figure 3. Total $\mathrm{N}$ in senescent leaves of semideciduous and deciduous legume trees with and without simbiotic $\mathrm{N}$ fixation (SNF): Hc - Hymenaea courbaril (semideciduous - without SNF), Lg - Lonchocarpus guilleminianus (semideciduous - with SNF), $P d$ - Peltophorum dubium (deciduous - without SNF), and Ec - Enterolobium contortisiliquum (deciduous - with SNF). Bars indicate standard deviation $(\mathrm{n}=3)$. Different letters indicate differences between species (Duncan 5\%). DM = dry mass.
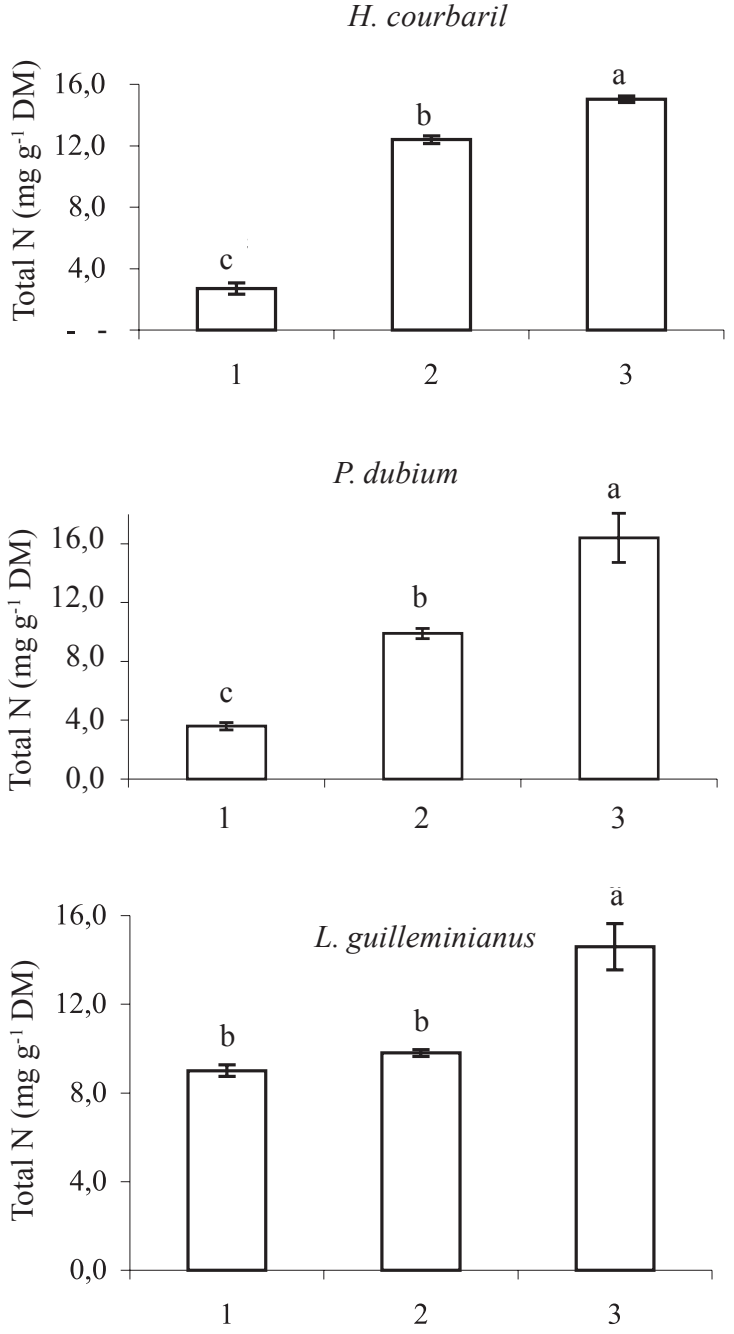

E. contorsiliquum

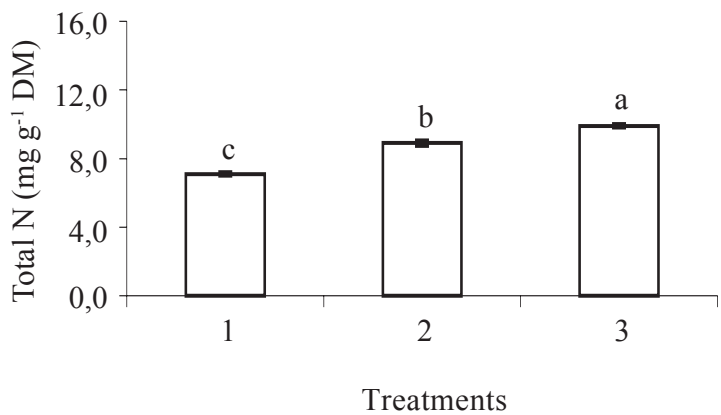

Figure 4. Total $\mathrm{N}$ in senescent leaves of semideciduous and deciduous legume trees with and without simbiotic $\mathrm{N}$ fixation (SNF): Hymenaea courbaril (semidecíduous - without SNF), Lonchocarpus guilleminianus (semidecíduous - with SNF), Peltophorum dubium (deciduous - without SNF), and Enterolobium contortisiliquum (deciduous - with SNF). Plants were grown in different soils: 1 - soil from the forest, 2 - soil from the forest enriched with $50 \mathrm{mg}$ of $\mathrm{NH}_{4} \mathrm{NO}_{3}$ plant $^{-1}$ week ${ }^{-1}$ and 3 - soil from the forest enriched with $100 \mathrm{mg}$ of $\mathrm{NH}_{4} \mathrm{NO}_{3}$ plant ${ }^{-1}$ week $^{-1}$. Bars indicate standard deviation of means $(n=3)$. Different letters indicate differences between treatments (Duncan 5\%). DM = dry mass. 
increase in the concentration of $\mathrm{N}$ in the senescent leaves of the four species (Fig. 4).

$\mathrm{N}$-use efficiency (NUE) for the two species without SNF was higher for the semideciduous species than for the deciduous ones (Fig. 5). Similar data were obtained by Haddad et al. (2004) when comparing H. courbaril with another deciduous species, Croton priscus, form the Santa Genebra Reserve.

An increase in the availability of $\mathrm{N}$ through SNF (Fig. 5) or by the addition of this mineral to the soil (Fig. 6) resulted in lower NUE values, confirming previous reports (Vitousek 1982; Knops et al. 1997; Cordell et al. 2001; Distel et al. 2003). According to Feller et al. (1999) and Hiremath et al. (2002) the NUE value is inversely proportional to soil nutrient availability. They concluded that this parameter helps to explain the species distribution in natural communities, since the species with a greater efficiency in using minerals are more adapted to colonize less fertile environments.

In conclusion, the $\mathrm{N}$ conservation mechanisms (NRE, NRP and NUE) of the four legume trees species decreased with the increase of $\mathrm{N}$ concentration in the soil and with SNF. When comparing the species without SNF, the species with a longer leaf life span (H. courbaril) had more efficient $\mathrm{N}$ conservation mechanisms. No relationship was found between leaf life span and $\mathrm{N}$ conservation mechanisms in the species that fix $\mathrm{N}_{2}$. It is possible that L. guilleminianus is more efficient at conserving $\mathrm{N}$ if it grows in environments with a low availability of $\mathrm{N}$ and/or in the absence of nitrogen fixing bacteria. Since only four species were compared in this study, further studies with a larger number of semideciduous forest species, with different leaf life spans, are necessary in order to obtain a more

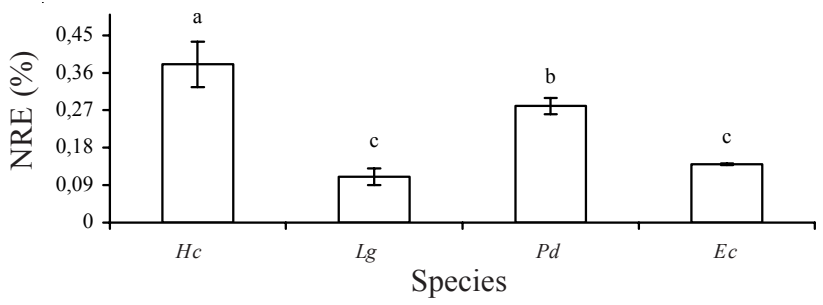

Figure 5. N use efficiency (NUE) of semideciduous and deciduous legume trees with and without simbiotic $\mathrm{N}$ fixation (SNF): Hc - Hymenaea courbaril (semidecíduous - without SNF), Lg - Lonchocarpus guilleminianus (semidecíduous - with SNF), Pd - Peltophorum dubium (deciduous - without SNF), and Ec - Enterolobium contortisiliquum (deciduous - with SNF). Bars indicate standard deviation of means $(=3)$. Different letters indicate differences between species (Duncan 5\%). DM = dry mass.
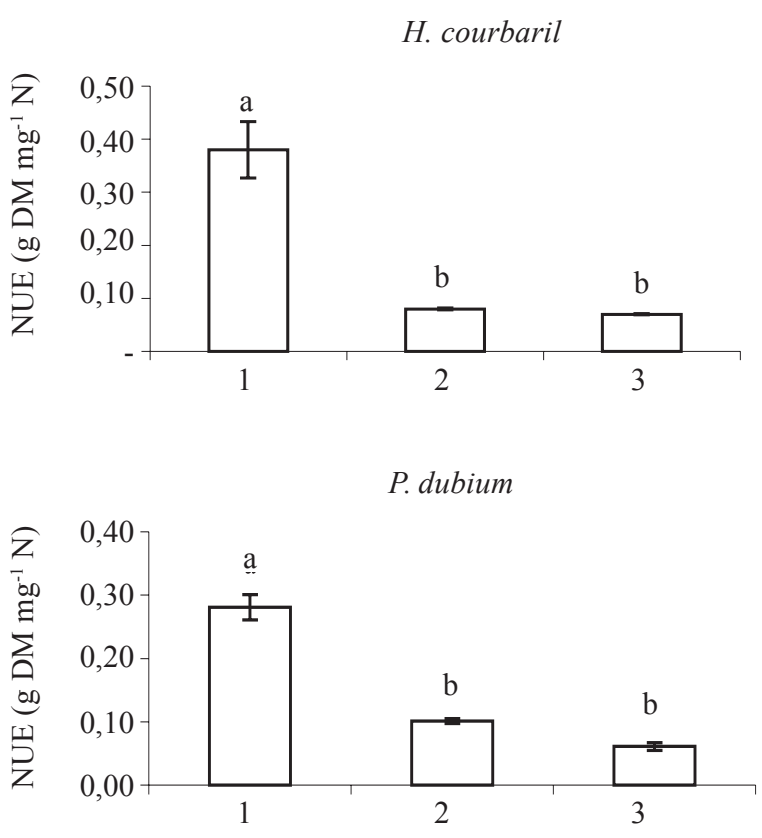

L. guilleminianus

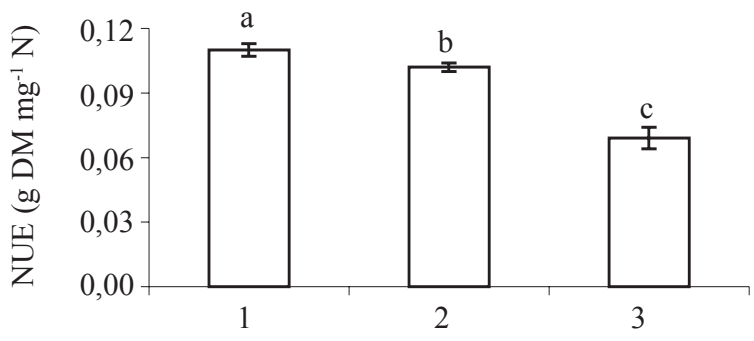

E. contorsiliquum

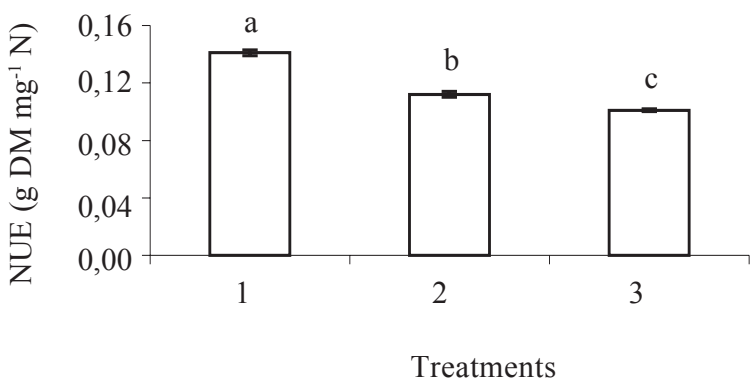

Figure 6. N use efficiency (NUE) of semideciduous and deciduous legume trees with and without simbiotic $\mathrm{N}$ fixation (SNF): H. courbaril (semideciduous - without SNF), L. guilleminianus (semideciduous - with SNF), P. dubium (deciduous - without $\mathrm{SNF}$ ), and E. contortisiliquum (deciduous - with SNF). Plants were grown in different soils: 1 - soil from the forest, 2 - soil from the forest enriched with $50 \mathrm{mg}$ of $\mathrm{NH}_{4} \mathrm{NO}_{3}$ plant $^{-1}$ week ${ }^{-1}$ and 3 - soil from the forest enriched with $100 \mathrm{mg}$ of $\mathrm{NH}_{4} \mathrm{NO}_{3}$ plant $^{-1}$ week $^{-1}$. Bars indicate standard deviation of means $(n=3)$. Different letters indicate differences between treatments (Duncan $5 \%) . \mathrm{DM}=$ dry mass. 
general picture of the relationship between $\mathrm{N}$ conservation mechanisms and leaf life spans in this type of environment.

\section{Acknowledgements}

To Fundação José Pedro de Oliveira (Reserva Mata de Santa Genebra), for granting permission to collect seeds and soil. To Anne d'Heursel for revising the English version of the manuscript. Ana Lúcia S. Lima is grateful to Coordenação de Aperfeiçoamento de Pessoal de Nível Superior (CAPES), for the fellowship and to the Centro Universitário Luterano de Jí-Paraná, Universidade Luterana do Brasil, (CEULJI/ULBRA), for financial support.

\section{References}

Aerts, R. 1995. The advantages of being evergreen. Trends in Ecology \& Evolution 10: 402-407.

Aerts, R. 1996. Nutrient resorption from senescing leaves of perennials: are there general patterns? Ecology 84: 597-608.

Aerts, R.; Verhoeven, J.T.A. \& Whigham, D.F.1999. Plantmediated controls on nutrient cycling in temperate fens and bogs. Ecology 80: 2170-2181.

Anderson, W.B. \& Eickmeier, W.G. 2000. Nutrient resorption in Claytonia virginica L.: implications for deciduous forest nutrient cycling. Canadian Journal of Botany 78: 832-839.

Becana, M.; Gorgocena, Y.; Aparicio-Tejo, P.M. \& Sánches-Días, Í.M. 1986. Nitrogen fixation and leghemoglobin content during vegetative growth of alfalfa. Journal of Plant Physiology 123: 117-125.

Berendese, F. 1994. Litter decomposability - a neglected component of fitness. Functional Ecology 82: 187-190.

Bradford, M.M. 1976. A rapid and sensitive method for the quantitation of microgram quantities of protein utilizing the principle of protein-dye binding. Analytical Biochemistry 72: 248-254.

Carrera, A.L.; Bertiller, M.B.; Sain, C.L. \& Mazzarino, M.J. 2003. Relationship between plant nitrogen conservation mechanisms and the dynamics of soil nitrogen in the arid Patagonian Monte, Argentina. Plant and Soil 255: 595-604.

Chapin, F.S. 1980. The mineral nutrition of wild plants. Annual Review of Ecology and Systematics 11: 233-260.

Cordell, S.; Goldstein, G.; Meinzer, F.C. \& Vitousek, P.M. 2001. Regulation of leaf life-span and nutrient-use efficiency of Metrosideros polymorpha trees at two extremes of a long chronosequence in Hawai. Oecologia 127: 198-206.

Côte, B. \& Dawson, J.O. 1986. Autumnal changes in total nitrogen, salt-extractable proteins and amino acids in leaves and adjacent bark of black alder, eastern cottonwood and white basswood. Physiologia Plantarum 67: 102-108.
Côte, B.; Vogel, C.S. \& Dawson, J.O. 1989. Autumnal changes in tissue nitrogen of autumn olive, black alder and eastern cottonwood. Plant and Soil 118: 23-32.

Cresswell, A.; Gordon, A.J. \& Mytton, L.R. 1992. The physiology and biochemistry of cultivar-strain interactions in the white clover - Rhizobium symbiosis. Plant and Soil 139: 47-57.

Distel, R.A.; Moretto, A.S. \& Didoné, N.G. 2003. Nutrient resorption from senescing leaves in two Stipa species native to central Argentina. Austral Ecology 28: 210-215.

Eamus, D. \& Prichard, H.A. 1998. Cost-benefit analysis of leaves of four Australian savanna species. Tree Physiology 18: 537-545.

Eckstein, R.L.; Karlsson, P.S. \& Weih, M. 1999. Leaf life span and nutrient resorption as determinants of plant nutrient conservation in temperate-arctic regions. New Phytologist 143: 177-189.

Enoki, T. \& Kawagushi, H. 1999. Nitrogen resorption from needles of Pcitado porus thunbergii Parl. Growing along a topographic gradient of soil nutrient availability. Ecological Research 14: 1-8

Faria, S.M.; Lewis, G.P.; Sprent, J.I. \& Sutherland, J.M. 1989. Occurrence of nodulation in the Leguminosae. New Phytologist 111: 607-619.

Feller, I.C.; Whigham, D.F.; O’Neill, J.P. \& Mc Kee, K.L. 1999. Effects of nutrient enrichment on within-stand cycling in a mangrove forest. Ecology 80: 2193-2205.

Feller, I.C.; Mc Kee, K.L.; Whigham, D.F. \& O’Neill, J.P. 2003. Nitrogen vs phosphorus limitation across an ecotonal gradient in a mangrove forest. Biogeochemistry 62: 145-175.

Gomes, M.A.F. \& Sodek, L. 1984. Allantoinase and asparaginase activities in maturing fruits of nodulated and non-nodulated soybeans. Physiologia Plantarum 62: 105-109.

Gonçalves, C.A.; Goi, S.R. \& Neto, J.J. 1999. Crescimento e nodulação de Inga marginata em resposta à adição de $\mathrm{N}$, fósforo e inoculação com rizóbio. Floresta e Ambiente 6: $118-126$.

Guo, R.; Silsbury, J.H. \& Graham, R.D. 1992. Effect of four nitrogen compounds on nodulation and nitrogen fixation in faba bean, white lupin and medic plants. Australian Journal of Plant Physiology 19: 501-508.

Haddad, C.R.B.; Lemos, D.P. \& Mazzafera, P. 2004. Leaf life span and nitrogen in semideciduous forest tree species (Croton priscus and Hymenaea courbaril). Scientia Agricola 61: 462-465.

Hardy, R.W.F.; Holsten, R.D.; Jackson, E.K. \& Burns, R.C. 1968. The acetylene- ethylene assay for $\mathrm{N}_{2}$ fixation: laboratory and field evaluation. Plant Physiology 43: 1185-1207.

Hiremath, A.J.; Ewel, J.J. \& Cole, T.G. 2002. Nutrient use efficiency in three fast-growing tropical trees Forest Science 48: 662-672.

Jones, C.G.; Lawton, J.H. \& Shachak, M. 1994. Organisms as ecosystem engineers. Oikos 69: 373-386.

Killingbeck, K.T. 1993. Inefficient nitrogen resorption in genets of the actinorhizal nitrogen-fixing shrub Comptonia-peregrina-physiological ineptitude or evolutionary tradeoff. Oecologia 94: 542-549. 
Killingbeck, K.T. 1996. Nutrients in senesced leaves: keys to the search for potential resorption and resorption proficiency. Ecology 77: 1716-1727.

Killingbeck, K.T. \& Whitford, W.G. 2001. Nutrient resorption in shrubs growing by design, and by default in Chihuahuan Desert arroyos. Oecologia 128: 351-359.

Knops, J.M.H.; Koening, W.D. \& Nash, III T.H. 1997. On the relationship between nutrient use efficiency and fertility in forest ecosystems. Oecologia 110: 550-556.

Lal, C.B.; Anapurna, C.; Raghubanshi, A.S. \& Singh, J.S. 2001. Effect of leaf habit and soil type on nutrient resorption and conservation in woody species of a dry tropical environment. Canadian Journal of Botany 79: 1066-1075.

Lorenzi, H. 1992. Árvores brasileiras. Nova Odessa, Editora Plantarum.

May, J.D. \& Killingbeck, K.T. 1992. Effects of preventing nutrient resorption on plant fitness and foliar nutrient dynamics. Ecology 73: 1868-1878.

Morellato, L.P.C.; Rodrigues, R.R.; Leitão Filho, H.F. \& Joly, C.A. 1989. Estudo comparativo de fenologia de espécies arbóreas de florestas de altitude e mesófila semidecídua na Serra do Japi, Jundiaí, São Paulo. Revista Brasileira de Botânica 12: 85-89.

Morellato, L.P.C. \& Leitão Filho, H.F. 1995. Ecologia e preservação de uma floresta tropical urbana - Reserva de Santa Genebra. Campinas, Editora da Unicamp.

Nelson, D.W. \& Sommers, L.E. 1973. Determination of the total nitrogen in plant material. Agronomy Journal 65: 109-112.
Oliveira, J.B. Menk, J.R.F. \& Rotta, C.L. 1979. Levantamento pedológico semidetalhado dos solos do Estado de São Paulo (quadrícula de Campinas). Série Recursos Naturais e Meio Ambiente $n^{\circ}$ 5, IBGE.

Pugnaire, F.I. \& Chapin, F.S. 1993. Controls over nutrient resorption from leaves of evergreen Mediterranean species. Ecology 74: 124-129.

SAS/STAT. 1990. Users guide. Version 8. Cary, SAS Institute Inc. CD-Room.

Smart, C.M. 1994. Gene expression during leaf senescence. New Phytologist 126: 419-448.

Sprent, J.I. 2001. Nodulation in legumes. Kew, The Cromwell Press.

Streeter, J.G. 1988. Effect of nitrate in the rooting medium on the carbohydrate composition of soybean nodules. Plant Physiology 68: 840-844.

Vincent, J.M. 1970. A manual for practical study of the rootnodule bacteria. Oxford, Blackwell Scientific Publications.

Vitousek, P. 1982. Nutrient cycling and nutrient use efficiency. The American Naturalist 119: 553-572.

Vitousek, P.M. 1984. Litterfall, nutrient cycling and nutrient limitation in tropical forest. Ecology 65: 285-298.

Waterer, J.G. \& Vessey, J.K. 1993. Effect of low static nitrate concentrations on mineral nitrogen uptake, nodulation, and fixation in field pea. Journal of Plant Nutrition 16: 1775-1789.

Wright, I.J. \& Westoby, M. 2003. Nutrient conservation, resorption and lifespan: leaf traits of Autralian sclerophyll species. Functional Ecology 17: 10-19. 